\section{Auricular Myiasis in Children: Case report of Unexpected Foreign Bodie}

\author{
Ballage A, Chaouki A*, Beghdad M, Mkhatri A, Abada R, \\ Rouadi S, Roubal M and Mahtar M
}

Department of ENT, University Hospital Centre IBN ROCHD, North Africa

\begin{abstract}
Myiasis is the invasion and feeding on living tissues of humans or animals by fly larvae; The aural myiasis is not a common infestation, rare in adults but frequent in children with neglected chronic suppurative otorrhea and poor personal hygiene.

The most common pathological symptoms of aural myiasis are otalgia and otorrhea, the diagnosis is usually through physical examination, and rarely through diagnostic images. There are no published guidelines for diagnosis or treatment of this disease.

We report a case of a child with aural myiasis, living in a rural area in Casablanca morocco, with a maggot at the right ear; in treatment a combination of maggot extraction, Saline irrigation, concomitant suction and $3 \mathrm{mg}$ of ivermectine were administrated with an encouraging results.
\end{abstract}

\section{Introduction}

The term myiasis is derived from the Greek word "myia" meaning fly, was first created by Hope (1840). This term referred to the only clinical manifestations caused in humans by dipterous larvae (maggots), as opposed to those caused by insect larvae in general. [1] Subsequently, the meaning of the word has been extended to animal infestations which are also the more frequent because these larvae are essentially animals parasites and occasionally provoke human myiasis.

Auricular myiasis presents a rare and a unique clinical entity, it is rare in adults but frequent on among children; only a small number of

*Corresponding author: Chaouki A, Department of ENT, University Hospital Centre IBN ROCHD, North Africa; E-mail: anasschaouki.ac@gmail.com

Citation: Ballage A, Chaouki A, Beghdad M, Mkhatri A, Abada R, et al. (2019) Auricular Myiasis in Children: Case report of Unexpected foreign Bodie. J Otolaryng Head Neck Surg 5: 34

Received: July 04, 2019; Accepted: August 06, 2019; Published: August 13, 2019

Copyright: (c) 2019 Ballage A, et al., This is an open-access article distributed under the terms of the Creative Commons Attribution License, which permits unrestricted use, distribution, and reproduction in any medium, provided the original author and source are credited. case series have been reported [2]. Humans represent only a target of opportunity; it is frequent in rural and slum areas where unhygienic conditions are prevalent. Therefore, there is a Lack of available evidence to guide management of this disease [3]. We report a rare case of auricular myiasis on a child with immune deficiency history.

\section{Case Report}

A 2 years and 6 months old girl presented with a 2 years' history of chronic right ear otorrhea. The mother reports the notion of fever and otorrhea 6 months after birth, for which the girl has been hospitalized for 3 months in the infectious disease department, where the diagnosis of immune deficiency was evoked. (Blood Cell Count (CBC), Measurement of Oxidative Burst in Neutrophils, Expression of HLA-DR antigens, and immunologic tests were normal) different courses of oral and local antibiotics had been previously prescribed but were ineffective.

The girl has been referred to our ENT department for a complementary care management. The girl was admitted with the complaint of chronic otorrhea, otalgia and itching in the external auditory canal. The mother reported the extraction of maggots from the external auditory canal. CT scan showed a filling of the external auditory canal, middle ear and the mastoid cells without any bone lysis (Figure 1).

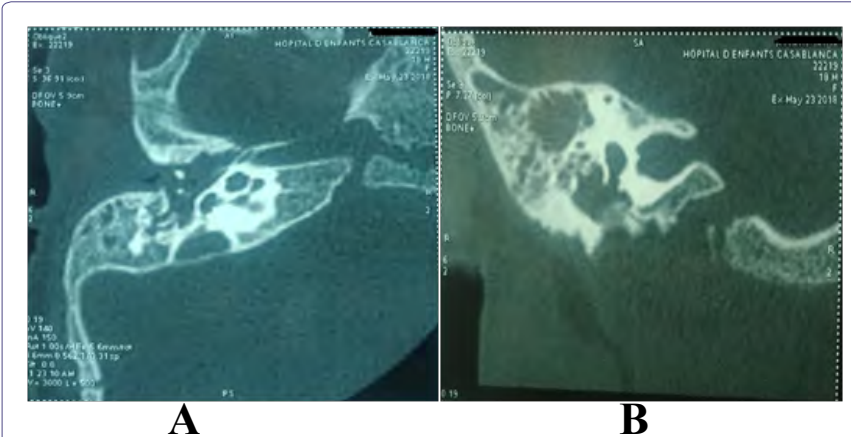

Figure 1: CT scan showing filling of the external auditory canal, middle ear and the mastoid cells (axial "A" and coronal" cut).

Upon examination with a general anesthesia, maggots showed at the middle ear after the aspiration of the draining right ear, with a large perforation. The maggots were extracted with clamp (Figure 2).

Saline irrigation and concomitant suction were performed. Combination antibiotic/steroid preparations were given pre- and post-micro toilet evacuation of the maggots, $3 \mathrm{mg}$ of ivermectine was administrated after extraction in one dose.

Maggot have been addressed in physiological saline at the parasitology laboratory and mycology, the myiasis was confirmed but fly species was not determined due to poor transport conditions, and the manipulated maggot. After 3 weeks follow up, the girl remained free of symptoms, and endoscopic examination showed the beginning of perforation closing (Figure 3). 
Citation: Ballage A, Chaouki A, Beghdad M, Mkhatri A, Abada R, et al. (2019) Auricular Myiasis in Children: Case report of Unexpected foreign Bodie. J Otolaryng Head Neck Surg 5: 34 .

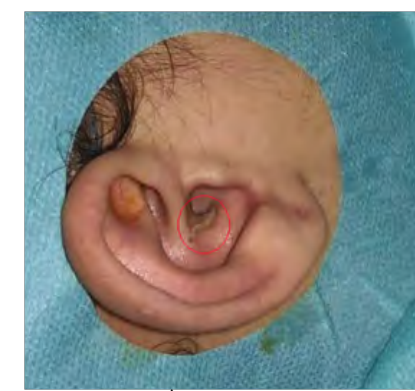

A

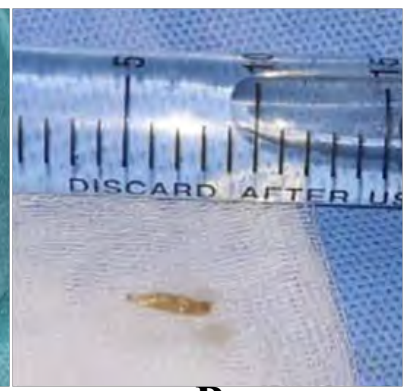

B

Figure 2: Maggot at the external auditory canal (A), and after extraction (B).

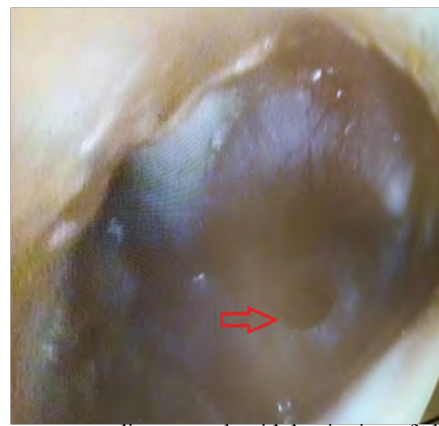

Figure 3: Clean extern auditory canal, with beginning of closing perforation.

\section{Discussion}

Myiasis is a type of parasites is which involves the infestation of living vertebrate animals with fly larvae which feed on host's necrotic or living tissue, liquid body substances or ingested food. Depending on the affected organ, myiasis can be classified in nasopharyngeal, oral, cutaneous, urogenital and, as in our case aural myiasis [3]. Aural myiasis has been defined as infestation of middle and/or the external ear, involvement of the pre-auricular region should also be included. A recent review article, considers that sanitary conditions, low socioeconomic status play an important role in general, however specifically aural myiasis has been previously suggested to be more common in children, in patients with chronic otorrhea, patients swimming in stagnant waters and/or in debilitated individuals $[2,4]$.

Neglected chronic suppurative otorrhea was the most suspicious cause in our case. The clinical presentation is wide from maggots in the ear to otalgia, ear drainage, Perforation of drum, itching roaring sound, tinnitus, bleeding. Otalgia is the most common pathological symptom of aural myiasis, otorrhea may be the second frequent symptom. Severe infestation may lead to deafness and meningitis. The surrounding tissue of the ear canal including bones may be damaged by the larval attack $[3,5]$. The examination of auditory function before and after treatment will be necessary if the patient repot hearing loss.

In our case the symptoms were the otorrhea and maggots in the ear; auditory function was not examined by audiogram. Taxonomic division establishes several families derived from the order Diptera: Oestridae, Calliphoridae and Sarcophagidae are the most important. The species Wohlfahrtia magnifica, which belongs to the latter family, is a must-type larva, meaning that it requires living in a host tissue to complete its development. This species is the predominant etiologic agent worldwide $[4,6]$.

In our population (morocco) sarcophagidae is the most frequent family [7], in our case fly species was not determined due to poor transport conditions. Singh and Rana (1989) reported that the identification of the species of maggot prior to the recommendation of treatment is important because not all types of myiasis are benign [5]; however in our case despite the lack of identification the outcomes were satisfactory.

After having diagnosed myiasis through physical examination and, in some cases, through diagnostic images, the treatment must begin as soon as possible, including removal of maggots and cleaning lesion with $70 \%$ ethanol, $10 \%$ chloroform, oil drops, iodine saline or normal saline. Prophylactic antibiotic therapy may prevent secondary infections. The treatment is simple in early stage $[4,5]$.

According to literature, maggot' sex traction, normal saline irrigation with concomitant suction and antibiotics were performed in our case. The ultimate goal of any treatment regimen is complete maggot removal and the easiest approach would likely be microscopic removal of all maggots with subsequent use of otic antibiotic drops [8]. Different studies have reported the occurrence of aural myiasis in humans [3], hence the interest of watchful waiting.

\section{Ethical Approval}

I certify that this kind of manuscript does not require ethical approval by the Ethical Committee of our institution.

\section{References}

1. Singh A, Singh Z (2015) Incidence of myiasis among humans-a review. Parasitology Research 114: 3183-3199.

2. Jervis Bardy J, Fitzpatrick N, Masood A, Crossland G, Patel H (2014) Myiasis of the ear. Annals of Otology, Rhinology \& Laryngology 124: 345-350.

3. Maturo S, Captain U, Michaelson PG, Brennan J (2007) Auricular myiasis. Otolaryngology-Head and Neck Surgery 136: 668-669.

4. Rodríguez Ruiz M, Acosta AM, Cifuentes Cardozo E, Chirveches M, Rosselli D (2018) Otomyiasis: systematic review. International Archives of Otorhinolaryngology 23: 104-109.

5. Yuca K, Çaksen H, Sakin YF, Yuca SA, Kiris M, et al. (2005) Aural myiasis in children and literature review. The Tohoku Journal of Experimental Medicine 206: 125-130.

6. Jervis-Bardy J, Fitzpatrick N, Masood A, Crossland G, Patel H (2015) Myiasis of the ear: A review with entomological aspects for the otolaryngologist. Ann Otol Rhinol Laryngol 124: 345-350.

7. Tligui H, Bouazzaoui A, Agoumi A, Otomyiases (2006) Humaines dues à Wohlfahrtia magnifica (Diptera : Sarcophagidae): A propos de trois observations au Maroc.

8. Steve Maturo, et al. (2007) Auricular myiasis; Otolaryngology-Head and Neck Surgery. 


\section{di}

Journal of Anesthesia \& Clinical Care

Journal of Addiction \& Addictive Disorders

Advances in Microbiology Research

Advances in Industrial Biotechnology

Journal of Agronomy \& Agricultural Science

Journal of AIDS Clinical Research \& STDs

Journal of Alcoholism, Drug Abuse \& Substance Dependence

Journal of Allergy Disorders \& Therapy

Journal of Alternative, Complementary \& Integrative Medicine

Journal of Alzheimer's \& Neurodegenerative Diseases

Journal of Angiology \& Vascular Surgery

Journal of Animal Research \& Veterinary Science

Archives of Zoological Studies

Archives of Urology

Journal of Atmospheric \& Earth-Sciences

Journal of Aquaculture \& Fisheries

Journal of Biotech Research \& Biochemistry

Journal of Brain \& Neuroscience Research

Journal of Cancer Biology \& Treatment

Journal of Cardiology: Study \& Research

Journal of Cell Biology \& Cell Metabolism

Journal of Clinical Dermatology \& Therapy

Journal of Clinical Immunology \& Immunotherapy

Journal of Clinical Studies \& Medical Case Reports

Journal of Community Medicine \& Public Health Care

Current Trends: Medical \& Biological Engineering

Journal of Cytology \& Tissue Biology

Journal of Dentistry: Oral Health \& Cosmesis

Journal of Diabetes \& Metabolic Disorders

Journal of Dairy Research \& Technology

Journal of Emergency Medicine Trauma \& Surgical Care

Journal of Environmental Science: Current Research

Journal of Food Science \& Nutrition

Journal of Forensic, Legal \& Investigative Sciences

Journal of Gastroenterology \& Hepatology Research

Journal of Gerontology \& Geriatric Medicine
Journal of Genetics \& Genomic Sciences

Journal of Hematology, Blood Transfusion \& Disorders

Journal of Human Endocrinology

Journal of Hospice \& Palliative Medical Care

Journal of Internal Medicine \& Primary Healthcare

Journal of Infectious \& Non Infectious Diseases

Journal of Light \& Laser: Current Trends

Journal of Modern Chemical Sciences

Journal of Medicine: Study \& Research

Journal of Nanotechnology: Nanomedicine \& Nanobiotechnology Journal of Neonatology \& Clinical Pediatrics

Journal of Nephrology \& Renal Therapy

Journal of Non Invasive Vascular Investigation

Journal of Nuclear Medicine, Radiology \& Radiation Therapy

Journal of Obesity \& Weight Loss

Journal of Orthopedic Research \& Physiotherapy

Journal of Otolaryngology, Head \& Neck Surgery

Journal of Protein Research \& Bioinformatics

Journal of Pathology Clinical \& Medical Research

Journal of Pharmacology, Pharmaceutics \& Pharmacovigilance

Journal of Physical Medicine, Rehabilitation \& Disabilities

Journal of Plant Science: Current Research

Journal of Psychiatry, Depression \& Anxiety

Journal of Pulmonary Medicine \& Respiratory Research

Journal of Practical \& Professional Nursing

Journal of Reproductive Medicine, Gynaecology \& Obstetrics

Journal of Stem Cells Research, Development \& Therapy

Journal of Surgery: Current Trends \& Innovations

Journal of Toxicology: Current Research

Journal of Translational Science and Research

Trends in Anatomy \& Physiology

Journal of Vaccines Research \& Vaccination

Journal of Virology \& Antivirals

Archives of Surgery and Surgical Education

Sports Medicine and Injury Care Journal

International Journal of Case Reports and Therapeutic Studies 